\title{
Impact of FTA on Trade in ASEAN and Australia Using Customs Level Data
}

\author{
Shandre M. Thangavelu ${ }^{1,2+}$, Dionisius Narjoko ${ }^{3}$, and Shujiro Urata ${ }^{4}$ \\ ${ }^{1}$ Sunway University, Malaysia \\ ${ }^{2}$ University of Adelaide, Australia \\ ${ }^{3}$ Economic Research Institute for ASEAN and East Asia \\ ${ }^{4}$ Waseda University, Japan
}

\begin{abstract}
This study examines the impact of the Association of Southeast Asian Nations (ASEAN)-AustraliaNew Zealand Free Trade Agreement (AANZFTA) on Australian trade with a particular focus on imports from ASEAN member countries to Australia. We examine the AANZFTA's utilization by ten ASEAN countries at the six-digit trade classification level from 2012 to 2016 using Australian customs data. We implement Ando and Urata's (2018) and Hayakawa et al.'s (2014) framework of free trade agreement (FTA) utilization based on preferential tariff margins. We also account for overlapping FTAs that are likely to impact the AANZFTA's utilization. The results indicate that preferential tariff margins positively impact FTA utilization. However, the results also indicate that the AANZFTA's utilization rate across ASEAN countries is low relative to Australia's bilateral FTAs with Malaysia, Thailand, and Singapore. We also find evidence that co-sharing rules of origin positively impact FTA utilization.
\end{abstract}

Keywords: preferential tariffs, trade liberalization, preference erosion

JEL Classifications: F13, F15, F53

Received 17 June 2020, Revised 13 April 2021, Accepted 5 July 2021

\section{Introduction}

The Association of Southeast Asian Nations (ASEAN)-Australia-New Zealand Free Trade Agreement (AANZFTA) is a forward-looking free trade agreement (FTA) that integrates ASEAN with Australia and New Zealand in the Asia-Pacific region. It is a comprehensive agreement covering trade and services in the region and creates a free trade area of nearly 680 million people. It is also the third largest trading block with Australia after China and Europe, accounting for nearly US\$110.1 billion of bilateral trade in 2018. By comparison, China and Europe accounted

\footnotetext{
+Corresponding Author: Shandre M. Thangavelu

Professor, Vice-President, Jeffery Cheah Institute for Southeast Asia, Sunway University, Malaysia / Institute for International Trade, University of Adelaide, Australia. Email: Shandrethangavelu@gmail.com

Co-Author: Dionisius Narjoko

Senior Economist, Economic Research Institute for ASEAN and East Asia. Email: dion.narjoko@eria.org

Co-Author: Shujiro Urata

Professor, Waseda University, Japan. Email: surata@nifty.com
} 
for US\$194.6 billion and US\$118.6 billion of bilateral trade, respectively (Department of Foreign Affairs and Trade, 2019). The AANZFTA was signed at the $14^{\text {th }}$ ASEAN Summit in Thailand in January 2010. It was first regional agreement signed by these countries and was also the first such agreement that Australia and New Zealand signed jointly with other regional trading partners.

This study examines the impact of the AANZFTA on ASEAN in terms of trade, investment, and regional integration among ASEAN and Australia. Particularly, we examine the impact of the AANZFTA on the Australian imports from ASEAN countries and the development of the trade relationship between Australia and ASEAN countries. We analyze the evolution of trade and investment and changes in the direction, composition, and patterns of trade between ASEAN and Australia.

Over the past decade, ASEAN has entered into similar trade agreements with other countries in East and South Asia: the ASEAN-China FTA (ACFTA), the ASEAN-India FTA (AIFTA), the ASEAN-Japan Comprehensive Economic Partnership (AJCEP), and the ASEAN-Korea Free Trade Agreement (AKFTA). This study only examines the impact of the AANZFTA on Australian imports.

Previous studies measure FTA utilization in a few different ways. For example, the utility rate measures the share of the trade value of FTA-eligible products in total trade value (Candau et al., 2004). Some studies consider the number of trading firms that use FTAs relative to the total number of trading firms (Hayakawa et al., 2013a). However, the most common measure is the value of imports receiving preferential treatment as a share of the total value of imports that are eligible for preferential treatment (Hayakawa et al., 2013b; Keck \& Lendle, 2012; Pomfret et al., 2010).

Recent studies highlight the low utilization of regional FTAs by businesses, as they have mostly been adopted by larger businesses (Chia, 2010; Kawai \& Wignaraja, 2010; Tambunan \& Chandra, 2014). This finding raises important policy questions regarding the impacts of FTAs on overall business activities and trade policy in East Asia and ASEAN.

Several studies also highlight the learning and scale effects of FTAs. Kawai and Wignaraja (2010) find that utilization rates increase over time owing to a learning process in which firms require considerable time to learn and leverage their new preferences from FTAs. In addition to time and learning effects, Hayawaka et al. (2014) identify the margin, scale, and rules-oforigin (ROO) effects as the main determinants of FTA utilization. The proliferation of FTAs and the subsequent erosion of preferences (reduced margins) is potentially one of the most important reasons for the low utilization rates of FTAs by Japanese firms, as very few Japanese firms use the Japan-Singapore FTA owing to Singapore's near-zero most-favored nation (MFN) rates (Takahashi \& Urata, 2010). Studies show that the effects of preference margins on utilization rates (i.e., the margin effects) can vary considerably across importing countries. Hayakawa et al. (2014) find that the coefficient of the margin effect is around 0.01 in Korea, whereas Keck and Lendle (2012) find it to be 0.1 in the United States. The scale effect is the correlation 
between a high volume of imports in a specific sector and the utilization rate in that sector. Most studies conclude that the scale effect is positive, with elasticities varying across importing countries from around 0.03 to 0.07 (Hayakawa et al., 2014; Keck \& Lendle, 2012).

Finally, the ROO effect is perhaps the most common subject of recent studies, with the logic that more restrictive ROOs will reduce FTA utilization. Pomfret et al. (2010) and Keck and Lendle (2012) find that the ROO effect is significantly negative depending on the exact type of measurement and analysis (i.e., an ROO index versus a dummy variable approach). Hayakawa and Laksanapanyakul (2017) further expand upon this idea, finding that the harmonization of ROOs across different FTAs helps to reduce costs, thereby increasing utilization rates.

Several studies explore the impacts of FTAs and regional FTAs (RTAs) on trade using the gravity framework (Baier \& Bergstrand, 2007; Roy, 2010; Vicard, 2009). Most studies use dummy variables to capture the effects of FTAs and RTAs on trade creation and diversion. However, several issues can arise in estimating the gravity model. It is usually difficult to identify a good proxy variable for multilateral resistance terms, and most studies control for these effects through exporter-year and importer-year fixed effects (Anderson \& van Wincoop, 2003; Feenstra, 2002). Furthermore, zero-valued trade, which provides important information on firms' decisions to adopt FTAs and RTAs for their import and export activities, creates an issue (Melitz, 2003). Eliminating zero-valued observations by taking the logarithms of trade values may lead to the elimination of important information and selection bias in the model. Recent studies employ the pseudo-Poisson maximum likelihood technique to overcome this issue (Silva \& Tenreyro, 2006). Another critical issue in examining the impact of FTAs and RTAs using gravity models is overlapping FTAs. The dummy variable approach adopted in the gravity model framework cannot completely capture the effects of overlapping FTAs and is likely to under- or overestimate the impacts of FTAs and RTAs depending on the type of RTA (Vicard, 2009), the anticipatory effects of FTAs on trade (Mölders \& Volz, 2011), and the network effects of overlapping FTAs (Sopranzetti, 2017).

An alternative to the gravity model is capturing the actual effects of FTAs on firms by conducting surveys (Chia, 2010; Kawai \& Wignaraja, 2010; Tambunan \& Chandra, 2014). However, survey-based estimations of FTAs tend to highlight lower FTA utilization, and FTAs are only adopted by larger firms. The key issues with survey-based estimations are sample selection, as this method tends to focus on larger and exporting firms, and its inability to control for overlapping FTAs owing to a lack of firm-level information. Rather than using survey data, recent studies use administrative custom-level data at the product and firm level that capture actual FTA transactions to examine the effects of preferential margins on FTA utilization; these data provide a robust framework for analyzing FTA utilization (Ando \& Urata, 2018; Chang \& Hayakawa, 2014; Hayakawa et al., 2013a, 2014, 2018). For example, Hayakawa et al. (2018) observe a larger preferential margin between MFN and FTA tariff rates, which tends to positively 
impact FTA utilization rates. Recent studies also find a positive impact of FTA utilization in Asia and ASEAN. Chang and Hayakawa (2014) show that preferential margins under the Economic Cooperation Framework Agreement positively impact imports from China for Taiwanese firms. Based on similar customs data, studies find a positive impact of FTA utilization on Korean imports from ASEAN under the ASEAN-Korea FTA (Hayakawa et al., 2013a, 2014) and on Thailand's imports under its FTAs (Hayakawa \& Laksanapanyakul, 2017). Recent studies by Ando and Urata (2018) and Hayakawa and Shiino (2021) highlight the positive impact of FTAs on imports for Japanese FTAs. Studies also find a positive impact of FTAs on imports for Indonesia (Narjoko et al., 2018).

This study examines the utilization of the AANZFTA for ASEAN countries. We consider imports to Australia at the six-digit trade classification level from 2012 to 2016 using Australian customs data. We implement the FTA utilization framework of Ando and Urata (2018) and Hayakawa et al. (2013a, 2014) based on preferential tariff margins. We account for overlapping FTAs that will likely affect FTA utilization and for both multilateral and bilateral FTAs across the countries in our study. The results show that the preferential margin is positive, indicating a positive impact on FTA utilization. However, we also find that the AANZFTA's utilization rates are low across ASEAN countries relative to those of bilateral FTAs with Malaysia, Thailand, and Singapore. Additionally, we find exporting effects in Indonesia, Malaysia, Philippines, and Vietnam. The learning effects of using FTAs are also strong and statistically significant in this setting. Finally, we find evidence that including a co-sharing ROO in an FTA tends to increase its utilization.

The remainder of this paper is organized as follows. Section 2 provides an overview of the macroeconomic trends in ASEAN and Australia and their trade relationship. Section 3 summarizes the FTAs completed by Australia. In Section 4, we describe the FTA utilization rate and the empirical model used to examine FTA utilization. Section 5 provides a policy conclusion.

\section{Trade and Integration between ASEAN and Australia: The AANZFTA}

ASEAN is a multiregional economic union among Southeast Asian countries created in 1967 that seeks international cooperation among its members and other countries worldwide. It has established a range of important regional arrangements, including ASEAN-plus-one FTAs, such as the ASEAN-India, ASEAN-China, and ASEAN-Korea Free Trade Areas, and the Comprehensive Economic Partnership for East Asia. It has also completed negotiations for the Regional Comprehensive Economic Partnership (RCEP). Trade liberalization and economic cooperation have become important strategies for ASEAN countries to engage in globalization and improve within the global production value chain. The potential trade impacts of East Asian and ASEAN-plus-one 
FTAs are given in Table 1A in the Annex. The RCEP is clearly the largest trading block in the world, covering $28 \%$ of global GDP, $29 \%$ of world trade, $25 \%$ of global FDI, and nearly $30 \%$ of the global population in 2018. In 2018, the AANZFTA framework covered nearly 680 million people ( $9 \%$ of the global population). The countries in the agreement had a combined real GDP of US\$4.39 trillion (5\% of global GDP), total trade of US\$1.93 trillion (5\% of world trade), and total FDI inflows of US\$288 billion (15\% of global FDI). ASEAN was the third largest trading block with Australia after China and Europe in 2018.

\section{A. AANZFTA}

ASEAN, Australia, and New Zealand established their first tripartite FTA, the AANZFTA, in 2009. The AANZFTA came into effect on January 1, 2010, and has been implemented by all of the countries involved, with tariff reduction initiatives starting in October 2015. The AANZFTA is a comprehensive, high-quality FTA that ASEAN completed with Australia and New Zealand in 2010. It is a living FTA that is subject to periodic reviews to ensure that it remains high quality and relevant to changing, dynamic business activities and regional economic integration and growth. In 2017, the AANZFTA was reviewed, and the FTA Joint Committee

Table 1. Tariff Elimination Coverage by Country under ASEAN-plus-one FTAs

\begin{tabular}{|c|c|c|c|c|c|}
\hline & ASEAN-ANZ & ASEAN-China & ASEAN-India & ASEAN-Japan & ASEAN-Korea \\
\hline BRN & $99.2 \%$ & $98.3 \%$ & $85.3 \%$ & $97.7 \%$ & $99.2 \%$ \\
\hline CAM & $89.1 \%$ & $89.9 \%$ & $88.4 \%$ & $85.7 \%$ & $97.1 \%$ \\
\hline IDN & $93.7 \%$ & $92.3 \%$ & $48.7 \%$ & $91.2 \%$ & $91.2 \%$ \\
\hline LAO & $91.9 \%$ & $97.6 \%$ & $80.1 \%$ & $86.9 \%$ & $90.0 \%$ \\
\hline MLS & $97.4 \%$ & $93.4 \%$ & $79.8 \%$ & $94.1 \%$ & $95.5 \%$ \\
\hline MYA & $88.1 \%$ & $94.5 \%$ & $76.6 \%$ & $85.2 \%$ & $92.2 \%$ \\
\hline PHI & $95.1 \%$ & $93.0 \%$ & $80.9 \%$ & $97.4 \%$ & $99.0 \%$ \\
\hline SGP & $100.0 \%$ & $100.0 \%$ & $100.0 \%$ & $100.0 \%$ & $100.0 \%$ \\
\hline THA & $98.9 \%$ & $93.5 \%$ & $78.1 \%$ & $96.8 \%$ & $95.6 \%$ \\
\hline VTN & $94.8 \%$ & n.a. & $79.5 \%$ & $94.4 \%$ & $89.4 \%$ \\
\hline AUS & $100.0 \%$ & - & - & - & - \\
\hline $\mathrm{CHN}$ & - & $94.1 \%$ & - & - & - \\
\hline IND & - & - & $78.8 \%$ & - & - \\
\hline JPN & - & - & - & $91.9 \%$ & - \\
\hline KOR & - & - & - & - & $90.5 \%$ \\
\hline NZ & $100.0 \%$ & - & - & - & - \\
\hline Average & $95.7 \%$ & $94.7 \%$ & $79.6 \%$ & $92.8 \%$ & $94.5 \%$ \\
\hline
\end{tabular}

Note: The data use a Harmonized System (HS) six-digit base. Data on Vietnam under the ASEAN-China FTA are missing. Data on Myanmar under the ASEAN-China FTA are also missing for HSO1-HSO8.

(Source) Fukunaga and Isono (2013) 
highlighted its key achievements from 2010 to 2017 as extensive reductions in tariffs, regional ROOs that facilitated business in the global supply chain, many World Trade Organization-plus commitments in services, investor protection and facilitation, and an effective framework for economic cooperation and technical capacity building (FTA Joint Committee, 2017).

The AANZFTA is important for Australia and New Zealand, as it is the largest regional FTA for both countries (FTA Joint Committee, 2017). According to a 2016 report by the Australian Department of Foreign Affairs and Trade (DFAT), ASEAN countries comprised $14.3 \%$ of total trade with Australia in 2015, including $11.7 \%$ of Australia's exports and $16.2 \%$ of its imports.

Among the existing ASEAN-plus-one FTAs, the AANZFTA is the most liberal, with a commitment to eliminate more than $95 \%$ of tariff lines (Fukunaga \& Isono, 2013). Table 1 shows the tariff elimination targets under the ASEAN-plus-one FTAs. The FTA members in the tables correspond to Australia and New Zealand for the AANZFTA, China for the ACFTA, India for the AIFTA, Japan for the AJCEP, and Korea for the AKFTA.

\section{Analysis of Trade among AANZFTA Members}

\section{A. Trade in goods between ASEAN and Australia-New Zealand}

ASEAN's total exports to Australia are shown in Figure 1. ASEAN's total global exports expanded significantly after the global financial crisis from US\$811 billion in 2009 to US $\$ 1,295$ billion in 2014. However, they declined to US\$1,161 billion in 2015. The intra-ASEAN share of total exports remained stable at $25 \%$ during this time.

ASEAN's exports of goods to Australia and New Zealand (ANZ) increased after the rebound from the global financial crisis in 2009 and the establishment of the AANZFTA in 2010. ANZ's share of ASEAN's total exports was $4.2 \%$ in 2009 but declined to $3.6 \%$ in 2015.

The export intensity indexes (i.e., the ratio of a country's or region's share of exports to ASEAN-ANZ to the share of intra-ASEAN-ANZ imports in total imports excluding imports from that country or region) of both group and individual members of the FTA are greater than one on average based on our analysis (see Figure 2). The export intensity index is higher on average in ASEAN than in ANZ. The indexes of Laos, Myanmar, Singapore, Malaysia, and Brunei are relatively higher, indicating that exports from these countries to the AANZFTA region are more intense. 
Figure 1. ASEAN exports (USD billion)

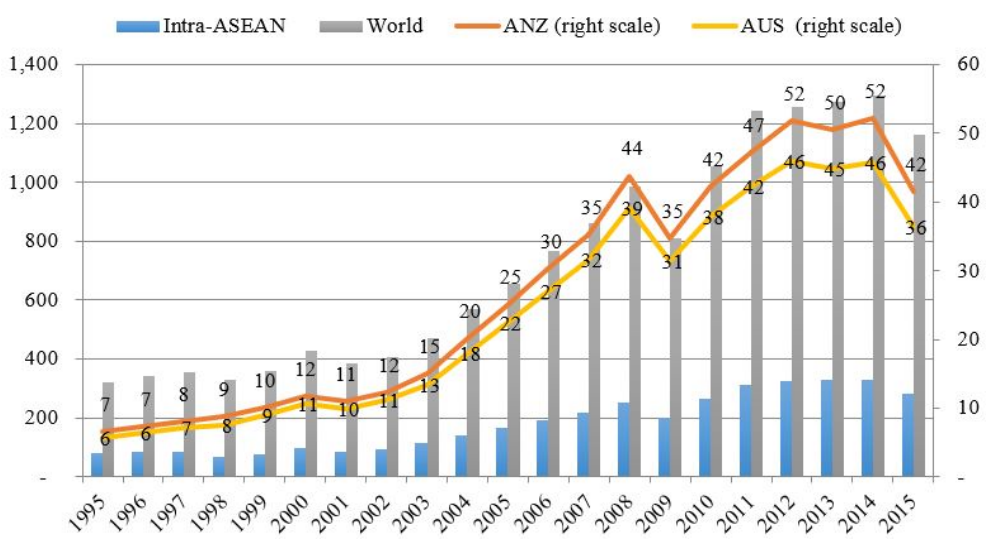

(Source) Computed from United Nations Conference on Trade and Development (UNCTAD), Handbook of Statistics (2017).

Figure 2. ASEANand ANZ export intensity indexes

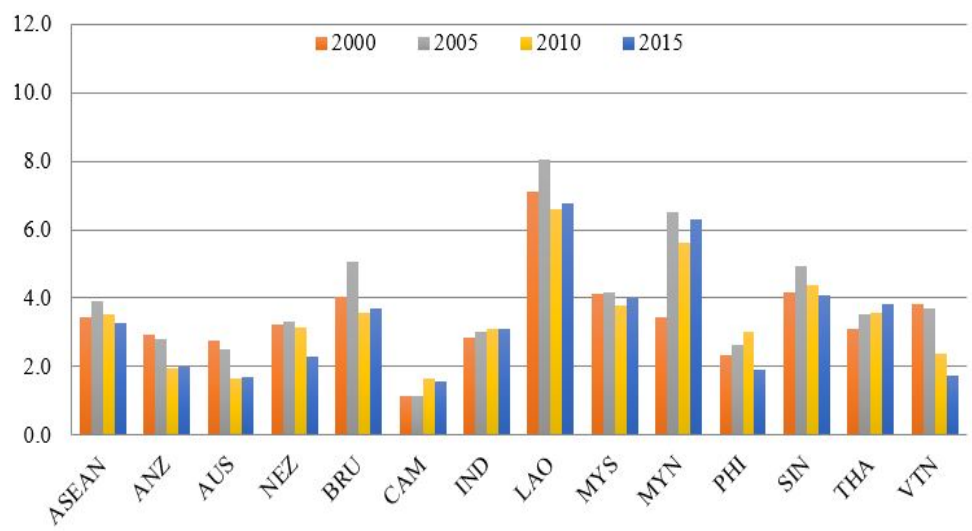

(Source) Computed from UNCTAD, Handbook of Statistics (2017).

Among the top products exported from ASEAN to ANZ are petroleum, automotive parts and components, telecommunications, and electronics (see Table 2). The average annual growth of these product exports was relatively higher from 2005 to 2010 than from 2010 to 2015 .

Similarly, ASEAN's total imports increased from US\$730 billion in 2009 to US\$1,234 billion in 2014 but declined to US\$1,092 billion in 2015 (see Figure 3). ASEAN's imports from ANZ increased from US\$18 billion in 2009 to US\$29 billion in 2014 before declining to US\$24 billion in 2015. The share of intra-ASEAN imports was 23\%, and ANZ's share of total imports was $2 \%$ in 2015 . 
Table 2. Top Ten Commodity Exports from ASEAN to ANZ (Million USD)

\begin{tabular}{|c|c|c|c|c|c|c|c|c|}
\hline & \multicolumn{4}{|c|}{ 2005-2010 (Average) } & \multicolumn{4}{|c|}{ 2010-2015 (Average) } \\
\hline & & Value & Share & Growth & & Value & Share & Growth \\
\hline 1 & $\begin{array}{l}\text { [333] Petroleum oils, oils from } \\
\text { bituminous materials, crude }\end{array}$ & 8,700 & $20.6 \%$ & $15.8 \%$ & $\begin{array}{l}\text { [334] Petroleum oils or } \\
\text { bituminous minerals }>70 \% \text { oil }\end{array}$ & 2,357 & $12.1 \%$ & $4 \%$ \\
\hline 2 & $\begin{array}{l}\text { [334] Petroleum oils or } \\
\text { bituminous minerals }>70 \% \text { oil }\end{array}$ & 6,465 & $15.3 \%$ & $20.4 \%$ & $\begin{array}{l}\text { [333] Petroleum oils, oils from } \\
\text { bituminous materials, crude }\end{array}$ & 1,687 & $10.5 \%$ & $0 \%$ \\
\hline 3 & $\begin{array}{l}\text { [971] Gold, non-monetary (excluding } \\
\text { gold ores and concentrates) }\end{array}$ & 2,572 & $6.1 \%$ & $50.5 \%$ & $\begin{array}{l}\text { [782] Motor vehicles for the } \\
\text { transport of goods, special purposes }\end{array}$ & 1,652 & $7.2 \%$ & $20 \%$ \\
\hline 4 & $\begin{array}{l}\text { [782] Motor vehicles for the } \\
\text { transport of goods, special purposes }\end{array}$ & 1,751 & $4.1 \%$ & $18.6 \%$ & $\begin{array}{l}\text { [781] Motor vehicles for the } \\
\text { transport of persons }\end{array}$ & 1,157 & $5.0 \%$ & $21 \%$ \\
\hline 5 & $\begin{array}{l}\text { [781] Motor vehicles for the } \\
\text { transport of persons }\end{array}$ & 1,514 & $3.6 \%$ & $73.9 \%$ & $\begin{array}{l}\text { [752] Automatic data processing } \\
\text { machines, not elsewhere specified }\end{array}$ & 1,013 & $3.7 \%$ & $8 \%$ \\
\hline 6 & $\begin{array}{l}\text { [752] Automatic data processing } \\
\text { machines, not elsewhere specified }\end{array}$ & 1,351 & $3.2 \%$ & $1.8 \%$ & $\begin{array}{l}\text { [691] Structures \& parts, not } \\
\text { elsewhere specified, of iron, steel, } \\
\text { or aluminum }\end{array}$ & 840 & $3.4 \%$ & $44 \%$ \\
\hline 7 & $\begin{array}{l}\text { [761] Television receivers, whether } \\
\text { or not combined }\end{array}$ & 1,198 & $2.8 \%$ & $50.5 \%$ & $\begin{array}{l}\text { [764] Telecommunication equipment, } \\
\text { not elsewhere specified, \& parts, not } \\
\text { elsewhere specified }\end{array}$ & 826 & $2.9 \%$ & $25 \%$ \\
\hline 8 & $\begin{array}{l}\text { [759] Parts, accessories for } \\
\text { machines of groups }\end{array}$ & 1,091 & $2.6 \%$ & $3.8 \%$ & $\begin{array}{l}\text { [098] Edible products and } \\
\text { preparations, not elsewhere specified }\end{array}$ & 797 & $2.2 \%$ & $40 \%$ \\
\hline 9 & $\begin{array}{l}\text { [741] Heating \& cooling equipment \& } \\
\text { parts thereof, not elsewhere specified }\end{array}$ & 598 & $1.4 \%$ & $10.5 \%$ & $\begin{array}{l}\text { [759] Parts, accessories for } \\
\text { machines of groups } 751,752\end{array}$ & 663 & $1.9 \%$ & $-2 \%$ \\
\hline 10 & [776] Cathode valves \& tubes & 504 & $1.2 \%$ & $13.1 \%$ & $\begin{array}{l}\text { [679] Tubes, pipes \& hollow } \\
\text { profiles, fittings, iron, steel }\end{array}$ & 631 & $1.9 \%$ & $17 \%$ \\
\hline
\end{tabular}

Note: Shares are shares of total exports. Growth in 2010 is average annual growth from 2005 to 2010, and growth in 2015 is average annual growth from 2010 to 2015.

(Source) Computed from UNCTAD Statistics (2017).

Figure 3. ASEAN imports (USD billions)

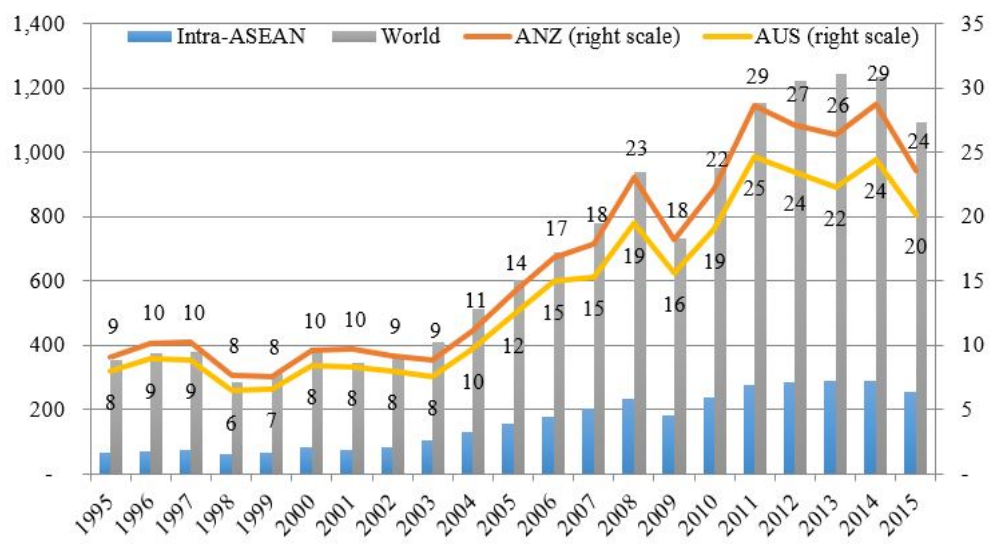

(Source) Computed from UNCTAD, Handbook of Statistics (2017). 
The import intensity indexes (i.e., the ratio of a country's or region's share of imports to ASEAN-ANZ to the share of intra-ASEAN-ANZ exports in total exports excluding exports from that country or region) of both group and individual members of the AANZFTA are also greater than one on average (see Figure 4). The import intensity index is highest for Laos, followed by Cambodia, Myanmar, and Brunei, indicating that these countries' imports from the AANZFTA region are very important.

Figure 4. ASEAN and ANZ import intensity indexes

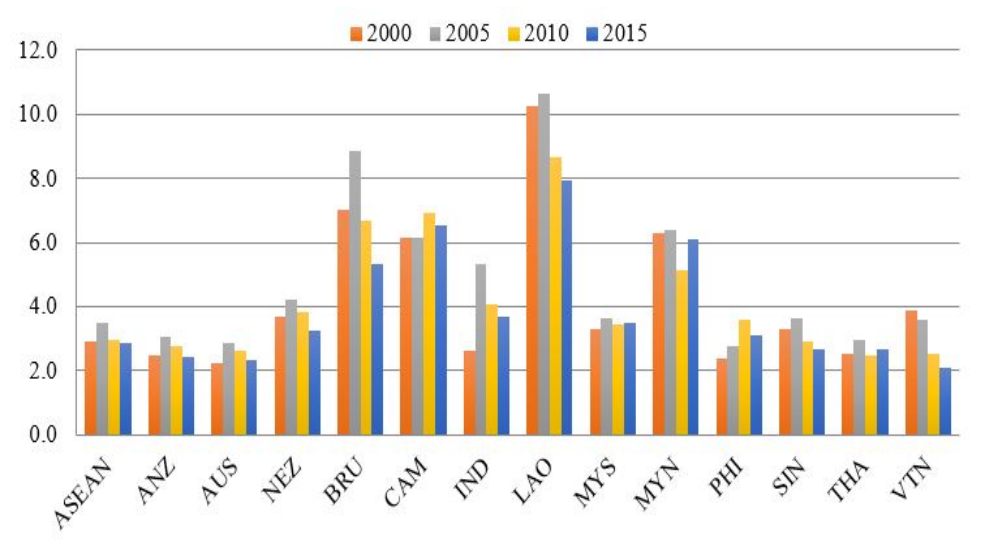

(Source) Computed from UNCTAD, Handbook of Statistics (2017).

ASEAN mostly imports petroleum, gold, milk, wheat, live animals, meats, and mineral products from ANZ (see Table 3). These products ranked among the top products in both 2010 and 2015. Like exports, imports of these products grew relative more quickly from 2005 to 2010 than from 2010 to 2015 , except in the case of natural gas, whose imports increased more than ninefold on average between 2010 and 2015 . 
Table 3. Top Ten Commodity Imports from ANZ to ASEAN (Million USD)

\begin{tabular}{|c|c|c|c|c|c|c|c|c|}
\hline & \multicolumn{4}{|c|}{ 2005-2010 (Average) } & \multicolumn{4}{|c|}{ 2010-2015 (Average) } \\
\hline & & Value & Share & Growth & & Value & Share & Growth \\
\hline 1 & $\begin{array}{l}\text { [333] Petroleum oils, oils from } \\
\text { bituminous materials, crude }\end{array}$ & 3,065 & $13.8 \%$ & $21.8 \%$ & $\begin{array}{l}\text { [041] Wheat (including spelt) and } \\
\text { meslin, unmilled }\end{array}$ & 2,357 & $10.0 \%$ & $15 \%$ \\
\hline 2 & $\begin{array}{l}\text { [971] Gold, non-monetary (excluding } \\
\text { gold ores and concentrates) }\end{array}$ & 1,729 & $7.8 \%$ & $21.2 \%$ & $\begin{array}{l}\text { [333] Petroleum oils, oils from } \\
\text { bituminous materials, crude }\end{array}$ & 1,687 & $7.2 \%$ & $1 \%$ \\
\hline 3 & $\begin{array}{l}\text { [022] Milk, cream, and milk } \\
\text { products (excluding butter, cheese) }\end{array}$ & 1,682 & $7.6 \%$ & $12.4 \%$ & $\begin{array}{l}\text { [022] Milk, cream, and milk } \\
\text { products (excluding butter, cheese) }\end{array}$ & 1,652 & $7.0 \%$ & $7 \%$ \\
\hline 4 & $\begin{array}{l}\text { [041] Wheat (including spelt) and } \\
\text { meslin, unmilled }\end{array}$ & 1,627 & $7.3 \%$ & $23.8 \%$ & [683] Nickel & 1,157 & $4.9 \%$ & $202 \%$ \\
\hline 5 & [682] Copper & 978 & $4.4 \%$ & $16.7 \%$ & $\begin{array}{l}\text { [971] Gold, non-monetary (excluding } \\
\text { gold ores and concentrates) }\end{array}$ & 1,013 & $4.3 \%$ & $12 \%$ \\
\hline 6 & [684] Aluminum & 936 & $4.2 \%$ & $11.0 \%$ & [682] Copper & 840 & $3.6 \%$ & $10 \%$ \\
\hline 7 & $\begin{array}{l}\text { [011] Meat of bovine animals, fresh, } \\
\text { chilled, or frozen }\end{array}$ & 493 & $2.2 \%$ & $29.2 \%$ & [684] Aluminum & 826 & $3.5 \%$ & $-1 \%$ \\
\hline 8 & $\begin{array}{l}\text { [282] Ferrous waste, scrape; } \\
\text { remelting ingots, iron, steel }\end{array}$ & 460 & $2.1 \%$ & $33.4 \%$ & $\begin{array}{l}\text { [321] Coal, whether or not } \\
\text { pulverized, not agglomerated }\end{array}$ & 797 & $3.4 \%$ & $16 \%$ \\
\hline 9 & $\begin{array}{l}\text { [321] Coal, whether or not } \\
\text { pulverized, not agglomerated }\end{array}$ & 452 & $2.0 \%$ & $26.0 \%$ & $\begin{array}{l}\text { [011] Meat of bovine animals, fresh, } \\
\text { chilled, or frozen }\end{array}$ & 663 & $2.8 \%$ & $14 \%$ \\
\hline 10 & $\begin{array}{l}\text { [001] Live animals other than } \\
\text { animals of division } 03\end{array}$ & 442 & $2.0 \%$ & $16.8 \%$ & $\begin{array}{l}\text { [001] Live animals other than } \\
\text { animals of division } 03\end{array}$ & 631 & $2.7 \%$ & $13 \%$ \\
\hline
\end{tabular}

Note: Growth in 2010 is average annual growth from 2005 to 2010, and growth in 2015 is growth from 2010 to 2015. (Source) Computed from UNCTAD Statistics (2017).

\section{FTA Utilization and the Impact on Australian Imports: The AANZFTA}

\section{A. Data and methodology}

The data for this study are obtained from the Australian Customs Service agency, which collects detailed transaction-level data on trade entering Australia by country of origin and preference code for each six-digit HS classification (Australian Bureau of Statistics). We calculate the preference margins using MFN and AANZFTA tariff schedules sourced from the Australian DFAT1). Similarly, ROO data are compiled from the Product Specific Rules of Origin for AANZFTA, which are available from the DFAT2). The constructed dataset covers all imports into Australia between 2012 and 2016 from the ten ASEAN countries that are part of the AANZFTA.

We implement Hayakawa et al.'s (2013a, 2014) and Ando and Urata's (2018) framework for FTA utilization based on preferential tariff margins. The empirical model in our study is given as:

1) See the DFAT website: https://www.dfat.gov.au/trade/agreements/in-force/aanzfta/official-documents/Pages/annex-1 -schedules-of-tariff-commitments

2) https://www.dfat.gov.au/trade/agreements/in-force/aanzfta/official-documents/Pages/annex-2-to-the-agreement 


$$
U_{i p s t}=\alpha \cdot \operatorname{Margin}_{i p s t}+\beta \ln \operatorname{Import}_{i p t}+u+\epsilon_{i p s t},
$$

where $U_{\text {ipst }}$ is the utilization rate of FTA $s$ when importing product $p$ from country $i$ in year t. Margin ipst $_{\text {is }}$ the preference margin, defined as the difference between the FTA and MFN tariff rates on product $p$ from country $i$. We use average tariff rates, as tariff schedules are aggregated from the HS-10 level to the HS-6 level to match the customs clearance data (a summary of the average applied tariff rates on imports from ASEAN to Australia is provided in the Annex). Hayakawa and Laksanapanyakul (2017) find that the decision to aggregate preference margins based on minimums, maximums, or means has little effect on research outcomes. Import $_{i p t}$ is total imports of product $p$ from the world to country $i$ in year $t$. This variable controls for the effect of total demand for product $p$ in Australia. $\mathrm{u}$ is a vector of fixed effects.

The customs data used in this study also account for overlapping FTAs, and the model specification carefully controls for both multilateral FTAs, such as the AANZFTA, and countryspecific bilateral FTAs. For example, Malaysia, Singapore, and Thailand are in the AANZFTA and also have bilateral FTAs with Australia during our study period. Indonesia also has a bilateral FTA with Australia, but this agreement was only completed in July 2020.3) This study covers the multilateral AANZFTA and Australia's bilateral FTAs with Malaysia, Singapore, and Thailand, as our sample period spans 2012 to 2016. This period also spans the entries of Cambodia, Laos, and Myanmar into the AANZFTA.

We are interested in the coefficient in Equation (1), which reflects the impact of the preferential margin on the utilization rate. We expect the coefficient of the preferential margin to be positive, suggesting a positive impact of FTAs on the utilization rate. We also include the logarithm of imports to capture the scale effects of imports, as import volumes are highly correlated with utilization rates. We capture the learning effects of utilization using time fixed effects to show that the utilization rate increases over time owing to these effects. We also control for country-specific fixed effects. We include ROO dummies to capture the effects of ROOs (we discuss these dummies' construction more extensively in the next section).

The utilization rates are calculated using the following formula:

$$
U_{i p s t}=\frac{\text { Trade }_{\text {Value }} \text { ijpst }}{\text { Total Trade } \text { Value }_{i j p t}} \text {, }
$$

where $i$ is the importing country (Australia); $j$ is the exporting ASEAN country; $p$ is the product, as defined by six-digit HS code; $s$ is the FTA scheme, which in this case is always preference code $N$ for AANZFTA; and $t$ is the year. This variable takes a value in the range $[0,1]$.

3) See the DFAT website: https://www.dfat.gov.au/trade/agreements/in-force/aanzfta/Pages/asean-australia-new-zealan d-free-trade-agreement 


\section{B. Utilization of the AANZFTA by ASEAN}

Figure 5 shows the utilization rates of the AANZFTA for Australian imports in 2015 and 2016. The utilization rates are high for Indonesia, the Philippines, and Vietnam, as over 25\% of Australia's imports from these countries utilize the AANZFTA. Australian imports from Cambodia have an AANZFTA utilization rate of around 17\%, and Australian imports from Malaysia and Singapore both have AANZFTA utilization rates of around 12\%. We observe very low AANZFTA utilization by Brunei, Myanmar, Thailand, and Laos. Although we observe a sharp increase in AANZFTA utilization for Myanmar between 2015 and 2016, the average utilization rate for Australian imports from Myanmar over both years is around 6.5\%.

It is interesting to observe the overlapping effects of multilateral and bilateral FTAs in our sample. Table 4 shows imports' utilization rates for different import schemes and FTAs. In addition to the AANZFTA, we observe preferential rates for least developed countries (LDCs); developing countries; and Australia's bilateral FTAs with Malaysia, Thailand, and Singapore. We observe no preferential rates for imports to Australia at the six-digit product classification (see the DFAT website for various preferential schemes) ${ }^{4}$.

We find that the countries with overlapping FTAs with Australia, that is, Malaysia, Singapore, and Thailand, have lower AANZFTA utilization rates compared with countries covered only by the AANZFTA, such as Indonesia, the Philippines, and Vietnam. It is interesting to observe that Thailand prefers to use its bilateral FTA more than the AANZFTA, as the bilateral FTA has a utilization rate of $63 \%$, whereas the AANZFTA has a utilization rate of only $4 \%$. We also observe that Cambodia and Myanmar tend to use the LDC preferential rate more than

Figure 5. AANZFTA utilization rates by ASEAN countries for Australian imports, 2015-2016

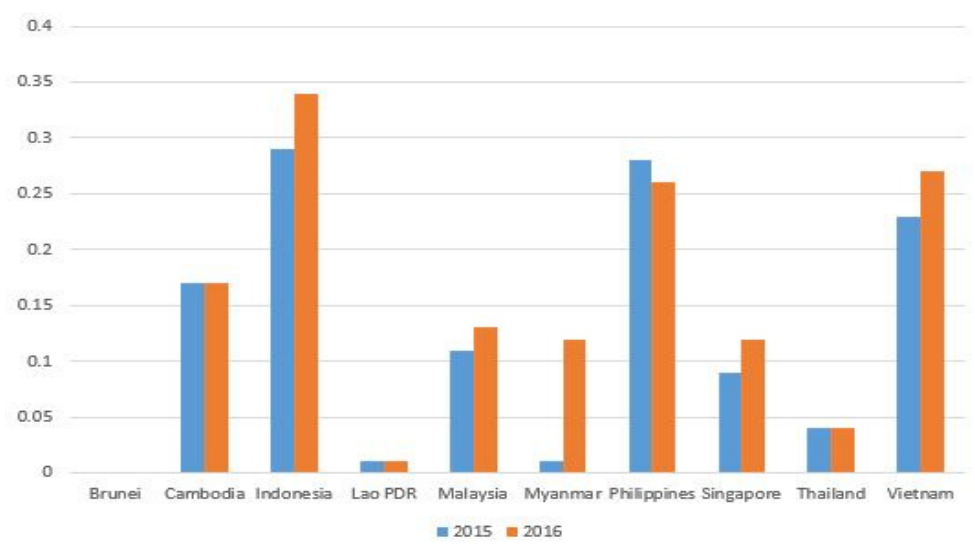

(Source) Authors.

4) The special preferential rates for LDCs, developing countries, and FTAs are provided on the DFAT website: https://www.abf.gov.au/importing-exporting-and-manufacturing/tariff-classification/current-tariff/schedule-1 
the AANZFTA rate for imports to Australia. The results also highlight that the AANZFTA's utilization rate for Australian imports from Singapore and Malaysia is greater than those of the bilateral FTAs between these countries and Australia.

Table 4. Utilization Rate of the AANZFTA for Australian Imports from ASEAN, 2007-2016

\begin{tabular}{|c|c|c|c|c|c|c|c|c|c|c|c|}
\hline Agreement & Code & 2007 & 2008 & 2009 & 2010 & 2011 & 2012 & 2013 & 2014 & 2015 & 2016 \\
\hline \multicolumn{12}{|c|}{ Brunei } \\
\hline AANZFTA & $\mathrm{N}$ & 0.00 & 0.00 & 0.00 & 0.00 & 0.00 & 0.00 & 0.00 & 0.00 & 0.00 & 0.00 \\
\hline No Pref. & $\mathrm{Z}$ & 1.00 & 1.00 & 1.00 & 1.00 & 1.00 & 1.00 & 1.00 & 1.00 & 1.00 & 1.00 \\
\hline \multicolumn{12}{|c|}{ Cambodia (Joined the AANZFTA in 2011) } \\
\hline AANZFTA & $\mathrm{N}$ & 0.00 & 0.00 & 0.00 & 0.00 & 0.04 & 0.08 & 0.10 & 0.13 & 0.17 & 0.17 \\
\hline LDCs & $\mathrm{L}$ & 0.36 & 0.87 & 0.83 & 0.84 & 0.76 & 0.60 & 0.63 & 0.69 & 0.63 & 0.52 \\
\hline No Pref. & $\mathrm{Z}$ & 0.61 & 0.10 & 0.15 & 0.13 & 0.19 & 0.28 & 0.23 & 0.16 & 0.17 & 0.29 \\
\hline Developing Country & $\mathrm{A}$ & 0.03 & 0.03 & 0.02 & 0.03 & 0.02 & 0.04 & 0.04 & 0.01 & 0.03 & 0.02 \\
\hline \multicolumn{12}{|c|}{ Indonesia } \\
\hline AANZFTA & $\mathrm{N}$ & 0.00 & 0.00 & 0.00 & 0.00 & 0.00 & 0.13 & 0.22 & 0.32 & 0.29 & 0.34 \\
\hline No Pref. & Z & 0.92 & 0.90 & 0.92 & 0.94 & 0.93 & 0.85 & 0.78 & 0.67 & 0.70 & 0.65 \\
\hline Developing Country & $\mathrm{T}$ & 0.08 & 0.10 & 0.08 & 0.06 & 0.07 & 0.02 & 0.01 & 0.01 & 0.01 & 0.02 \\
\hline \multicolumn{12}{|c|}{ Laos (Joined the AANZFTA in 2011) } \\
\hline AANZFTA & $\mathrm{N}$ & 0.00 & 0.00 & 0.00 & 0.00 & 0.08 & 0.01 & 0.00 & 0.09 & 0.01 & 0.01 \\
\hline LDCs & $\mathrm{L}$ & 0.04 & 0.23 & 0.74 & 0.24 & 0.16 & 0.00 & 0.01 & 0.62 & 0.57 & 0.02 \\
\hline No Pref. & $\mathrm{Z}$ & 0.93 & 0.68 & 0.18 & 0.36 & 0.71 & 0.99 & 0.99 & 0.29 & 0.42 & 0.96 \\
\hline Developing Country & A & 0.02 & 0.09 & 0.07 & 0.41 & 0.05 & 0.00 & 0.00 & 0.00 & 0.00 & 0.00 \\
\hline \multicolumn{12}{|c|}{ Malaysia } \\
\hline AANZFTA & $\mathrm{N}$ & 0.00 & 0.00 & 0.00 & 0.07 & 0.09 & 0.10 & 0.09 & 0.09 & 0.11 & 0.13 \\
\hline Developing Country & $\mathrm{T}$ & 0.05 & 0.06 & 0.05 & 0.02 & 0.01 & 0.01 & 0.01 & 0.01 & 0.01 & 0.01 \\
\hline MAFTA & M & 0.00 & 0.00 & 0.00 & 0.00 & 0.00 & 0.00 & 0.04 & 0.05 & 0.06 & 0.07 \\
\hline No Pref. & $\mathrm{Z}$ & 0.95 & 0.94 & 0.95 & 0.91 & 0.89 & 0.88 & 0.86 & 0.86 & 0.82 & 0.79 \\
\hline \multicolumn{12}{|c|}{ Myanmar } \\
\hline AANZFTA & $\mathrm{N}$ & 0.00 & 0.00 & 0.00 & 0.00 & 0.01 & 0.00 & 0.00 & 0.00 & 0.01 & 0.12 \\
\hline LDCs & $\mathrm{L}$ & 0.21 & 0.31 & 0.57 & 0.26 & 0.23 & 0.19 & 0.13 & 0.16 & 0.12 & 0.18 \\
\hline No Pref. & $\mathrm{Z}$ & 0.77 & 0.66 & 0.43 & 0.72 & 0.75 & 0.80 & 0.85 & 0.81 & 0.85 & 0.70 \\
\hline Developing Country & A & 0.02 & 0.03 & 0.01 & 0.02 & 0.01 & 0.01 & 0.02 & 0.03 & 0.02 & 0.00 \\
\hline \multicolumn{12}{|c|}{ Philippines } \\
\hline AANZFTA & $\mathrm{N}$ & 0.00 & 0.00 & 0.00 & 0.27 & 0.34 & 0.36 & 0.44 & 0.26 & 0.28 & 0.26 \\
\hline No Pref. & $\mathrm{Z}$ & 0.97 & 0.98 & 0.97 & 0.72 & 0.65 & 0.64 & 0.56 & 0.74 & 0.71 & 0.73 \\
\hline Developing Country & $\mathrm{T}$ & 0.03 & 0.02 & 0.03 & 0.01 & 0.01 & 0.01 & 0.00 & 0.00 & 0.01 & 0.01 \\
\hline \multicolumn{12}{|c|}{ Singapore } \\
\hline AANZFTA & $\mathrm{N}$ & 0.00 & 0.00 & 0.00 & 0.03 & 0.04 & 0.05 & 0.06 & 0.06 & 0.09 & 0.12 \\
\hline SAFTA & $\mathrm{P}$ & 0.03 & 0.02 & 0.02 & 0.02 & 0.02 & 0.01 & 0.01 & 0.01 & 0.02 & 0.01 \\
\hline No Pref. & Z & 0.96 & 0.97 & 0.97 & 0.94 & 0.93 & 0.94 & 0.93 & 0.92 & 0.88 & 0.86 \\
\hline
\end{tabular}


Table 4. Continued

\begin{tabular}{|c|c|c|c|c|c|c|c|c|c|c|c|}
\hline Agreement & Code & 2007 & 2008 & 2009 & 2010 & 2011 & 2012 & 2013 & 2014 & 2015 & 2016 \\
\hline \multicolumn{12}{|c|}{ Thailand } \\
\hline AANZFTA & $\mathrm{N}$ & 0.00 & 0.00 & 0.00 & 0.00 & 0.01 & 0.02 & 0.03 & 0.04 & 0.04 & 0.04 \\
\hline TAFTA & $\mathrm{H}$ & 0.59 & 0.54 & 0.41 & 0.56 & 0.57 & 0.61 & 0.64 & 0.66 & 0.65 & 0.63 \\
\hline Developing Country & $\mathrm{T}$ & 0.01 & 0.01 & 0.01 & 0.01 & 0.01 & 0.01 & 0.01 & 0.01 & 0.01 & 0.01 \\
\hline No Pref. & $\mathrm{Z}$ & 0.39 & 0.45 & 0.58 & 0.43 & 0.41 & 0.37 & 0.32 & 0.29 & 0.30 & 0.32 \\
\hline \multicolumn{12}{|c|}{ Vietnam } \\
\hline AANZFTA & $\mathrm{N}$ & 0.00 & 0.00 & 0.00 & 0.06 & 0.11 & 0.14 & 0.15 & 0.15 & 0.23 & 0.27 \\
\hline No Pref. & $\mathrm{Z}$ & 0.99 & 0.99 & 0.99 & 0.93 & 0.88 & 0.85 & 0.84 & 0.84 & 0.76 & 0.71 \\
\hline Developing Country & $\mathrm{T}$ & 0.01 & 0.01 & 0.01 & 0.01 & 0.01 & 0.01 & 0.01 & 0.01 & 0.01 & 0.02 \\
\hline
\end{tabular}

(Source) Authors. Notes: MAFTA: Malaysian-Australia FTA. TAFTA: Thailand-Australia FTA. SAFTA: Singapore-Australia FTA. Developing country: Developing country preferential rate. LDC: LDC preferential rates. No Pref.: No Preference. AANZFTA: ASEAN-Australia-New Zealand FTA.

\section{Empirical results}

To estimate the model, we first perform a baseline analysis using ordinary least squares (OLS) and then establish the robustness of the results of regressing utilization on margins and imports by including fixed effects. We include export dummies and time fixed effects to control for variations over time and country-specific issues. We also introduce exporter-year and exporterproduct fixed effects to control for the multilateral resistance term. We control for ROOs by introducing ROO dummies. Because we include a large number of variables through fixed effects, we implement the empirical framework using OLS with controls for the various fixed effects (Ando \& Urata, 2018; Hayakawa et al., 2013a, 2014).

Table 5 presents the results of the empirical model. The results are remarkably robust and tend to be in line with the findings of existing studies. An increase in the preference margin of 10 percentage points is expected to be associated with an increase in utilization of around 29 percentage points. This result is fairly similar to Keck and Lendle's (2012) finding. Specifically, they find a coefficient of 2.5 using data on Australian imports from 2008 and a similar regression model. This result is robust and statistically significant when controlling for exporter-year and exporter-product fixed effects; in that specification, the utilization rate increases by 21 percentage points when the preference margin increases by 10 percentage points.

The coefficient on the logarithm of imports is slightly lower than those found by Keck and Lendle (2012), which range from 0.03 to 0.08 . This difference may arise for several reasons, including differences in the time periods, FTA schemes, and methodologies used in the analysis. Our results imply that if imports were to double (i.e., increase by $100 \%$ ), utilization should increase by around 1.8 percentage points. When we control for exporter-year and exporter-product fixed effects, the coefficients of the margin and imports are slightly lower but are still positive 
Table 5. Effects of Preferential Margins on Utilization in the Case of the AANZFTA

\begin{tabular}{lcccccc}
\hline Variables & $(1)$ & $(2)$ & $(3)$ & $(4)$ & $(5)$ & $(6)$ \\
\hline Margin & $2.954 * * *$ & $2.987^{* * *}$ & $2.924^{* * *}$ & $2.846^{* * *}$ & $2.108^{* * *}$ & $2.143^{* * *}$ \\
& $(0.060)$ & $(0.057)$ & $(0.057)$ & $(0.058)$ & $(0.049)$ & $(0.049)$ \\
Ln (Imports) & $0.0180^{* * *}$ & $0.0186^{* * *}$ & $0.0183^{* * *}$ & $0.0186^{* * *}$ & $0.0138^{* * *}$ & $0.0137^{* * *}$ \\
& $(0.00057)$ & $(0.00056)$ & $(0.00056)$ & $(0.00056)$ & $(0.00056)$ & $(0.00052)$ \\
Constant & $-0.144^{* * *}$ & $-0.242^{* * *}$ & $-0.252^{* * *}$ & $-0.206 * * *$ & $-0.151^{* * *}$ & $-0.155^{* * *}$ \\
& $(0.0066)$ & $(0.023)$ & $(0.023)$ & $(0.025)$ & $(0.013)$ & $(0.014)$ \\
\hline Observations & 54,246 & 54,246 & 54,246 & 54,246 & 54,246 & 54.246 \\
Country-Product & 16,080 & 16,080 & 16,080 & 16,080 & 16,080 & 16,080 \\
R-Squared & 0.15 & 0.25 & 0.25 & 0.26 & 0.27 & 0.27 \\
\hline Exporter Dummies & NO & YES & YES & YES & YES & YES \\
Year Fixed Effects & NO & NO & YES & YES & YES & YES \\
ROO Dummies & NO & NO & YES & YES & YES & YES \\
Exporter-Year & NO & NO & NO & NO & YES & YES \\
Exporter-Product & NO & NO & NO & NO & NO & YES \\
\hline
\end{tabular}

Robust standard errors are in parentheses; *** $p<0.01,{ }^{* *} p<0.05, * p<0.1$

and statistically significant. In this specification, the coefficient on imports indicates that if imports increase by 100 percentage points, the utilization rate increases by 1.3 percentage points.

Whereas the results in columns (1) and (2) shed light on the margin and scale effects, the full results in columns (5) and (6) provide insights into the exporting country impacts, the learning effect, and the ROO effect (see Tables 6 to 8 ).

Table 6 shows the results including country-specific effects, such as domestic capacity and institutional factors that directly affect country-specific FTA utilization ${ }^{5)}$. With all other effects held constant, Indonesia, the Philippines, Vietnam, and Malaysia appear to experience the largest country-specific effects. We can conclude that these countries are positively associated with utilization for all FTAs, including the AANZFTA, as their average utilization rates are around 10-16 percentage points higher than that of Brunei (the baseline country). These results are statistically significant. In fact, Vietnam and Indonesia have the largest country effects of 15 and 16 percentage points, respectively. We also observe that the ASEAN LDCs of Cambodia, Laos, and Myanmar have statistically significant country effects of around two percentage points for all FTAs, including the AANZFTA.

5) The country effects capture overall country-specific factors and country-specific effects of FTA utilization for all overlapping FTAs, including the AANZFTA. 
Table 6. Impact of the AANZFTA and Utilization by Country

\begin{tabular}{lc}
\hline $\begin{array}{c}\text { Dependent Variable }=u \\
\text { Country Variables }\end{array}$ & Full Model \\
\hline Country of Origin $=2$, Cambodia & $0.019^{*}$ \\
Country of Origin $=3$, Indonesia & $(0.010)$ \\
Country of Origin $=4$, Laos & $0.150^{* * *}$ \\
Country of Origin $=5$, Malaysia & $(0.009)$ \\
Country of Origin $=6$, Myanmar & $0.024^{*}$ \\
Country of Origin $=7$, Philippines & $(0.013)$ \\
Country of Origin $=8$, Singapore & $0.112^{* * *}$ \\
Country of Origin $=9$, Thailand & $(0.009)$ \\
& $0.023^{* *}$ \\
& $(0.011)$ \\
\hline
\end{tabular}

The base country is Brunei.

Robust standard errors are in parentheses

*** $p<0.01, * * p<0.05, * p<0.1$

Table 7 illustrates the learning effects based on year-fixed effects of the AANZFTA. Although the year-fixed effects capture time variation, we assume that they also capture the learning effects of FTA utilization, as in Hayakawa et al. (2014). Taken in isolation and holding all other variables constant, these results clearly illustrate the learning effect6). The learning effect strengthens over time, as the coefficient on the year dummy is higher in year 5 (2016) than in year 2 (2013). The utilization rates of FTAs, including the AANZFTA, are expected to be around 0.8 percentage points higher in 2013 than in the baseline year of 2012. By 2016, this learning effect increases to around 3.1 percentage points. The learning effect is likely to capture learning-to-export effects and the administrative and other costs involved in seeking preferential rates for imports by the host country. The time-fixed effects may not completely capture the learning effects of FTAs, and, thus, we re-estimate the model with a lagged utilization rate. The results are given in Table A3 of the Annex. We observe that the lagged utilization rate has a positive and statistically significant impact, indicating that the adoption of an FTA for previous export

6) No specific systemic economic shocks to ASEAN countries occur during our sample period (2012-2016). Thus, we assume that the results for the time variation of FTA utilization capture learning effects. 
activities tends to positively affect the adoption of the FTA for current activities, supporting the existence of learning effects suggested by the time-fixed effects. We also observe positive and statistically significant impacts of preferential margins and imports on utilization rates, as in the baseline results.

Table 7. Impact of the AANZFTA and Utilization over Time (Learning Effects): 2012-2016

\begin{tabular}{lc}
\hline $\begin{array}{c}\text { Dependent Variable }=u \\
\text { Year Variables }\end{array}$ & $(4)$ \\
Year $=2,2013$ & Full Model \\
Year $=3,2014$ & $0.008^{* *}$ \\
Year $=4,2015$ & $(0.003)$ \\
& $0.005^{*}$ \\
Year $=5,2016$ & $(0.003)$ \\
& $0.004^{*}$ \\
& $(0.0021)$ \\
\hline
\end{tabular}

The base year is 2012 .

Robust standard errors are in parentheses.

*** $p<0.01, * * p<0.05, * p<0.1$

Many recent studies focus on ROO effects based on the idea that more restrictive ROOs reduce FTA utilization. Ando and Urata (2018), Pomfret et al. (2010), and Keck and Lendle (2012), among others, predictably find that ROO effects are significantly negative depending on the exact measurements of the ROO index, as compared to the dummy variable approach7). Hayakawa and Laksanapanyakul (2017) further expand upon this research, finding that the harmonization of ROOs across different FTAs reduces costs and thereby increases utilization rates. Ando and Urata's (2018) recent study of Japanese FTAs indicates that ROOs reduce the utilization rates of FTAs.

In this study, we map ROOs for the specific four-digit product classifications for the AANZFTA given on the DFAT website 8 ) to our custom data. ROOs at the specific product level are classified as wholly produced and obtained in the domestic economy (WO), regional value content (RVC), change in the tariff sub-heading at the six-digit level (CTSH), change in the trade heading at the four-digit level $(\mathrm{CTH})$, change in the commodity classification at the two-digit level (CC), and specific process (SP) rules. We also observe that more than one ROO may be applied to a specific product at the four-digit classification level. For example, both RVC and CTSH rules are applied for milk and cream products (tariff heading 0402).

7) Dummy variable approach accounts for impact of FTA with a binary variables of 0 and 1, which does not fully capture the full impact of the FTA utilization.

8) The ROOs for the AANZFTA are provided on the DFAT website: https:/www.dfat.gov.au/sites/default/files/annex2-product-specific-rules-first-protocol.pdf. 
We carefully map the ROO requirements at the six-digit product classification level, and the effects of ROOs on AANZFTA utilization rates are given in Table 8.

Table 8. Impact of the AANZFTA and Utilization by ROO Type

\begin{tabular}{|c|c|}
\hline Dependent Variable $=u$ & (6) \\
\hline ROO Variables (dummies in running order) & Full Model \\
\hline \multirow{2}{*}{$\mathrm{RoO}=2, \mathrm{CC}$ or $\mathrm{SPR}$} & $-0.019^{* *}$ \\
\hline & $(0.010)$ \\
\hline \multirow[t]{2}{*}{$\mathrm{RoO}=3, \mathrm{CC}+\mathrm{SPR}$} & -0.003 \\
\hline & $(0.012)$ \\
\hline \multirow[t]{2}{*}{$\mathrm{RoO}=4, \mathrm{CTH}$} & 0.015 \\
\hline & $(0.019)$ \\
\hline \multirow[t]{2}{*}{$\mathrm{RoO}=5, \mathrm{CTH}$ or $\mathrm{SPR}$} & $-0.035^{* *}$ \\
\hline & $(0.014)$ \\
\hline \multirow{2}{*}{$\mathrm{RoO}=6, \mathrm{RVC}$} & $-0.061 * * *$ \\
\hline & $(0.0128)$ \\
\hline \multirow[t]{2}{*}{$\mathrm{RoO}=7, \mathrm{RVC}+\mathrm{CTSH}$} & 0.052 \\
\hline & $(0.051)$ \\
\hline \multirow[t]{2}{*}{$\mathrm{RoO}=8, \mathrm{RVC}$ or $\mathrm{CC}$} & $-0.034 * * *$ \\
\hline & $(0.010)$ \\
\hline \multirow[t]{2}{*}{$\mathrm{RoO}=9, \mathrm{RVC}$ or $\mathrm{CC}$ or SPR } & $0.060^{* *}$ \\
\hline & $(0.026)$ \\
\hline \multirow[t]{2}{*}{$\mathrm{RoO}=10, \mathrm{RVC}$ or $\mathrm{CTH}$} & -0.007 \\
\hline & $(0.010)$ \\
\hline \multirow[t]{2}{*}{$\mathrm{RoO}=11, \mathrm{RVC}$ or $\mathrm{CTH}$ or $\mathrm{RVC}+\mathrm{CTSH}$} & $-0.030^{* *}$ \\
\hline & $(0.0107)$ \\
\hline \multirow[t]{2}{*}{$\mathrm{RoO}=12, \mathrm{RVC}$ or $\mathrm{CTH}$ or $\mathrm{SPR}$} & $-0.054 * * *$ \\
\hline & $(0.012)$ \\
\hline \multirow[t]{2}{*}{$\mathrm{RoO}=13, \mathrm{RVC}$ or $\mathrm{CTSH}$} & $-0.043 * * *$ \\
\hline & $(0.009)$ \\
\hline \multirow[t]{2}{*}{$\mathrm{RoO}=14, \mathrm{RVC}$ or $\mathrm{CTSH}$ or SPR } & $-0.054 * * *$ \\
\hline & $(0.011)$ \\
\hline \multirow[t]{2}{*}{$\mathrm{RoO}=15, \mathrm{RVC}$ or $\mathrm{SP}$} & -0.042 \\
\hline & $(0.029)$ \\
\hline \multirow[t]{2}{*}{$\mathrm{RoO}=16, \mathrm{SPR}$} & -0.001 \\
\hline & $(0.520)$ \\
\hline \multirow[t]{2}{*}{$\mathrm{RoO}=17, \mathrm{WO}$} & $-0.074 * * *$ \\
\hline & $(0.011)$ \\
\hline \multirow[t]{2}{*}{$\mathrm{RoO}=18, \mathrm{WO}$ or $\mathrm{SPR}$} & $-0.086^{* * *}$ \\
\hline & $(0.014)$ \\
\hline
\end{tabular}

For the ROO dummies, the baseline ROO is the CC rule. Robust standard errors are in parentheses.

$* * * p<0.01, * * p<0.05, * p<0.1$ 
In our analysis, we use $\mathrm{CC}$ rules as the baseline variable; hence, the results can be interpreted relative to this baseline. The results indicate that ROOs have an overall negative impact on FTA utilization. We also observe that flexibility in the application of ROOs in terms of co-sharing rules, such as RVC or CC rules, or SP rules (see ROO dummy 9 at Table 8) positively impacts FTA utilization. This positive impact is relative to the impacts of more restrictive rules, such as CC rules, relative to RVC and SP rules (Medalla, 2011).

To provide more clarity on our ROO results, we compare our results to those of Medalla (2011). Medalla and Rosellon's (2012) and Medalla's (2011) studies of ASEAN's bilateral and multilateral FTAs highlight the difficulty of converging ROOs across the different FTAs in terms of global production value chain activities. Without identifying specific information on the ROOs and the production processes, it is difficult to determine whether one rule is less restrictive than another rule. However, Ando and Urata (2018) and Medalla and Rosellon (2012) highlight several observations. First, the lower the required minimum for RVC is, the less restrictive the $\mathrm{ROO}$ is. Second, the higher the product classification digit level is in a change in tariff classification rule, the less restrictive the ROO is. Third, a greater number of SP rules implies that an ROO is more restrictive.

Medalla (2011) creates an ROO restrictiveness index and ranks ROOs in terms of their restrictiveness on FTA utilization. The study highlights the following findings:

(a) $\mathrm{CTSH}$ rules are less restrictive than $\mathrm{CTH}$ rules, rules limiting $\mathrm{RVC}$ to be no less than $40 \%$, and SP rules. In turn, these rules are less restrictive than $\mathrm{CC}$ and $\mathrm{WO}$ rules (i.e., $\mathrm{CTSH}<\mathrm{CTH}, \mathrm{RVC}(40), \mathrm{SPR}<\mathrm{CC}<\mathrm{WO})$;

(b) co-equal sharing rules that allow exporters to choose one of two rules are less restrictive; and

(c) requirements to comply with more than one rule (plus rather than either/or rules) are more restrictive.

We also summarize our results in Table 9 with Medalla's (2011) ROO restrictiveness index given in parentheses. We map the statistically significant coefficients of the ROO dummies in our study and map them on to Medalla's (2011) ROO restrictiveness index. We define a coefficient above -0.03 as indicating very low ROO restrictiveness, a coefficient between -0.03 to -0.06 as indicating a medium level of restrictiveness, and a coefficient below -0.06 as highly restrictive.9) The cut-offs used in this study are somewhat arbitrary, but they provide a good basis for understanding the impacts of ROOs on FTA utilization. The results do not change when we vary the cut-offs in a sensitivity test.

9) We vary the cut-offs in a sensitivity study and find no impact on the results obtained in our study. 
Table 9. ROOs and Levels of Restrictions

\begin{tabular}{|c|c|c|}
\hline Low & Medium & High \\
\hline CC or $\mathrm{SPR}^{*}[3.7]$ & RVC or $\mathrm{CTSH}^{*}[3.6]$ & $\mathrm{RVC}^{*}[4.0]$ \\
\hline \multirow[t]{5}{*}{$\mathrm{RVC}$ or $\mathrm{CC}$ or $\mathrm{SPR}^{* *}[3.5]$} & $\mathrm{RVC}$ or $\mathrm{CTH}$ or $\mathrm{RVC}+\mathrm{CTSH}^{*}[3.5]$ & WO* [6] \\
\hline & RVC or CTSH or SPR** [3.5] & WO or SPR* [4.6] \\
\hline & $\mathrm{RVC}$ or $\mathrm{CTH}$ or $\mathrm{SPR}^{*}[3.5]$ & \\
\hline & CTH or SPR* [3.6] & \\
\hline & $\mathrm{RVC}$ or $\mathrm{CC}^{*}[3.7]$ & \\
\hline
\end{tabular}

Low: coefficient $>-0.03$; Medium: $-0.03>$ coefficient $>-0.06$; High: $-0.06>$ coefficient

Only statistically significant coefficients are included.

Medalla's (2011) ROO restrictiveness index is given in parentheses. This index falls in the range [0,1], with values closer to one indicating greater restrictiveness.

* indicates statistical significance at the $5 \%$ level, ** indicates statistical significance at the $10 \%$ level

The results of our study support Medalla's (2011) observations. First, we observe that coequal sharing rules are less restrictive than situations in which compliance with more than one rule is required. In our study, co-equal sharing rules that allow exporters (importers) to choose one of two rules tends to positively impact FTA utilization. For example, the option to choose an RVC, CC, or SP rule has a statistically significantly positive impact on FTA utilization. We also observe that the option to choose an $\mathrm{RVC}, \mathrm{CTH}$, or SP rule and the option to choose an RVC, CTSH, or SP rule both have less negative impacts on FTA utilization relative to compliance with one rule, such as a WO or RVC rule. This result is also statistically significant. Second, we observe that WO rules have greater negative impacts on FTA utilization and, thus, are more restrictive than SP and CTH rules. However, we also observe that RVC and WO rules are restrictive without any co-equal sharing rules. In fact, we find that WO rules are highly restrictive, as Medalla (2011) verifies, but that they become less restrictive with a co-sharing rule. Third, we find that compliance with more than one rule, as in the cases of $\mathrm{RVC}+\mathrm{CTSH}$ and $\mathrm{CC}+\mathrm{SPR}$ rules, has no statistically significant effect in our analysis. Such rules are less likely to be adopted by businesses and tend to be restrictive, as in Medalla (2011).

\section{Policy Conclusion}

This study examined the impact of the AANZFTA on Australian trade and, in particular, on Australian imports from ASEAN member states. We explicitly examined the AANZFTA's utilization by ten ASEAN countries at the six-digit trade classification level from 2012 to 2016 using Australian customs data. We also empirically implemented the model of FTA utilization based on preferential tariff margins introduced by Ando and Urata (2018) and Hayakawa et al. (2014). The study accounted for both multilateral and bilateral FTAs across the countries that are part of the AANZFTA. 
The results indicate that the preferential margin has a positive impact on FTA utilization. However, the results also indicate that the utilization rates of the AANZFTA across ASEAN countries are low relative to those of Australia's bilateral FTAs with Malaysia, Thailand, and Singapore. We also find exporting effects in Indonesia, Malaysia, Philippines, and Vietnam. Finally, we identify strong learning effects of using FTAs.

The low utilization rate of the AANZFTA is concerning, as ASEAN is emerging as one of Australia's key trade and investment partners. The AANZFTA renegotiation started in September 2018, where the Ministers at the $23^{\text {th }}$ ASEAN Economic Ministers meeting on 1 September 2018 adopted the first stage recommendations of the Joint FTA Committee with the implementation in 2019 and second stage negotiation to follow immediately after ${ }^{10)}$, where the renegotiated AANZFTA is expected to increase its preferential margin and, thus, its utilization rate.

The restrictiveness of ROOs must be reduced to increase the FTA's utilization and its relevance to businesses. The recent review of and amendments to the FTA between Singapore and Australia (Third Review of FTA) on ROOs provide a framework for doing so (see the DFAT website $\left.{ }^{11}\right)$. The amendments improve the co-equal sharing rule and also introduce RVC as a new method for determining whether a good originates from the relevant country. This new policy reduces costs and administrative complications and can generally be applied to ROOs under the AANZFTA. The procedures for claiming preferential treatment will also be modernized based on these amendments. Traders can now self-certify that their goods meet the ROOs. These procedures will also provide exporters with the flexibility to continue having their goods certified by a third party. These revisions and amendments are critical to increasing the utilization and relevance of FTAs, and, thus, increasing trade and investment in the region.

\section{References}

Anderson J., \& Van Wincoop, E. (2003). Gravity with gravitas: A solution to the border puzzle. American Economic Review, 93, 170-192.

Ando, M., \& Urata, S. (2018). Determinants of FTA utilization for Japan's imports: Preferential margins and restrictiveness of rules of origin (RIETI Discussion Paper Series 18-E-078). Research Institute of Economy, Trade and Industry, Japan.

Baier, S. L., \& Bergstrand, J. H. (2007). Do free trade agreements actually increase members' international trade? Journal of International Economics, 71(1), 72-95.

Candau, F., Fontagné, L., \& Jean, S. (2004). The utilisation rate of preferences in the EU. Paper presented

10) https://www.dfat.gov.au/sites/default/files/aanzfta-general-review-recommendations.pdf

11) https://www.dfat.gov.au/trade/agreements/in-force/safta/Pages/singapore-australia-fta). 
at the 7th Global Economic Analysis Conference, Washington D.C., June 17-19, 2004.

Chang, K., \& Hayakawa, K. (2014). Details in the China-Taiwan free trade agreement. Journal of Economic Integration, 29, 676-699.

Chia S. Y. (2010). Trade and investment policies and regional economic integration in East Asia (ADBI Working Paper Series No. 10). Tokyo: Asian Development Bank Institute. Retrieved from http://www.a dbi.org/ les/2010.04.05.wp210.trade.investment.policies.east.asia.pdf

Department of Foreign Affairs and Trade. (2019). Trade and investment at a glance, 2019. Retrieved from https://www.dfat.gov.au/sites/default/files/trade-and-investment-at-a-glance-2019.pdf

Feenstra, R. C. (2002). Border effects and the gravity equation: Consistent methods for estimation. Scottish Journal of Political Economy, 49(5), 491-506.

FTA Joint Committee. (2017). General review of AANZFTA: Stage one of implementation 2010-2017, Department of Foreign Affairs and Trade. Retrieved from https://www.dfat.gov.au/trade/agreements/inforce/aanzfta/Pages/general-review-of-the-asean-australia-new-zealand-fta

Fukunaga, Y., \& Isono, I. (2013). Taking ASEAN+1 FTAs towards the RCEP: A mapping study (ERIA Discussion Paper Series 2013-02). ERIA, Jakarta.

Hayakawa, K., Hiratsuka, D., Shiino, K., \& Sukegawa, S. (2013a). Who uses free trade agreements? Asian Economic Journal, 27(3), 245-264.

Hayakawa, K., Kim, H. S., Laksanapanyakul, N., \& Shiino, K. (2013b). FTA utilization: Certificate of origin data versus customs data (IDE Discussion Papers 428). Institute of Developing Economies, Japan External Trade Organization.

Hayakawa, K., Kim, H., \& Lee, H. (2014). Determinants on utilization of the Korea-ASEAN free trade agreement: Margin effect, scale effect, and ROO effect. World Trade Review, 13(3), 499-515.

Hayakawa, K., \& Laksanapanyakul, N. (2017). Impacts of common rules of origin on FTA utilization. International Economics and Economic Policy, 14(1), 75-90.

Hayakawa, K., Laksanapanyakul, N., \& Yoshimi, T. (2018). Tariff scheme choice (IDE Discussion Papers 684). Institute of Developing Economies, Japan External Trade Organization.

Hayakawa, K., \& Shiino, K. (2021). Impact of the CPTPP on Japanese manufacturing affiliates in ASEAN. In C. Lee \& P. Bhattacharya (Eds.), The Comprehensive and Progressive Agreement for Trans-Pacific Partnership: Implications for Southeast Asia (pp. 162-178). ISEAS - Yusof Ishak Institute. Retrieved from https://bookshop.iseas.edu.sg/publication/2479

Kawai, M., \& Wignaraja, G. (2010). Asian FTAs: Trends, prospects, and challenges (Economics Working Paper Series No. 226). ADB.

Keck, A., \& Lendle, A. (2012). New evidence on preference utilization (WTO Staff Working Paper ERSD-2012-12). WTO, Geneva.

Medalla, E. (2011). Taking stock of the ROOs in the ASEAN +1 FTAs: Toward deepening East Asian integration (Philippines Institute for Development Studies, Discussion Paper, 2011-36). Manila, Philippines.

Medalla, E., \& Rosellon, M. A. D. (2012). Rules of origin in ASEAN +1 FTAs and the value chain in East Asia (Philippines Institute for Development Studies, Discussion Paper,2012-32). Manila, Philippines. 
Melitz, M. J. (2003). The impact of trade on intra-industry reallocations and aggregate industry productivity. Econometrica, 71(6), 1695-1725.

Mölders, F., \& Volz, U. (2011). Trade creation and the status of FTAs: Empirical evidence from East Asia. Review of World Economics, 147(3), 429-456.

Narjoko, D., Rafitrandi, D., \& Wicaksono, T. Y. (2018). RTA Utilization Rates in Indonesia (Project Report "Impact of FTA on Trade and Industry"). Economic Research Institute of ASEAN and East Asia (ERIA).

Pomfret, R., Kaufmann, U., \& Findlay, C. (2010). Use of FTAs in Australia (RIETI Discussion Paper Series 10-E-042). Research Institute of Economy, Trade and Industry (RIETI), Japan.

Roy, J. (2010). Do customs union members engage in more bilateral trade than free-trade agreement members? Review of International Economics, 18(4), 663-681.

Silva, J. M. C. S., \& Tenreyro, S. (2006). The log of gravity. Review of Economics and Statistics, 88(4), 641-658.

Sopranzetti, S. (2017). Overlapping free trade agreements and international trade: A network approach. The World Economy, 41(1), 1-18.

Takahashi, K., \& Urata, S. (2010). On the use of FTAs by Japanese firms: Further evidence. Business and Politics, 12(1), 2.

Tambunan, T., \& Chandra, A. (2014). Maximizing the utilization of ASEAN-led free trade agreements: The potential role of micro, small and medium-sized enterprises. Institute for Sustainable Development. United Nations Conference on Trade and Development (UNCTAD). (2017). Handbook of Statistics. United Nation Publications, New York. Retrieved from https://unctad.org/system/files/official-document/tdstat 42_en.pdf

Vicard, V. (2009). On trade creation and regional trade agreements: Does depth matter? Review of World Economics, 145, 167-187. 


\section{Annex}

Table A1. Global Standings of ASEAN and ANZ in 2018

\begin{tabular}{|c|c|c|c|c|c|c|c|c|}
\hline \multirow[b]{2}{*}{ World } & \multicolumn{2}{|c|}{$\begin{array}{c}\text { Real GDP } \\
\text { (Billion USD) }\end{array}$} & \multicolumn{2}{|c|}{ Trade (Billion USD) } & \multicolumn{2}{|c|}{$\begin{array}{l}\text { FDI Inflows } \\
\text { (Billion USD) }\end{array}$} & \multicolumn{2}{|c|}{$\begin{array}{l}\text { Population } \\
\text { (Billions) }\end{array}$} \\
\hline & $81,984.30$ & Share & $21,045.70$ & Share & $1,495.20$ & Share & 7.6 & Share \\
\hline United States & $19,611.80$ & 0.24 & $1,917.40$ & 0.09 & 253.5 & 0.17 & 0.33 & 0.04 \\
\hline China & $13,376.10$ & 0.16 & $2,624.90$ & 0.12 & 138.3 & 0.09 & 1.43 & 0.19 \\
\hline Japan & $4,536.90$ & 0.06 & 747.90 & 0.04 & 9.8 & 0.01 & 0.13 & 0.02 \\
\hline Germany & $3,573.90$ & 0.04 & $1,634.00$ & 0.08 & 73.5 & 0.05 & 0.08 & 0.01 \\
\hline France & $2,570.70$ & 0.03 & 620.30 & 0.03 & 38.1 & 0.03 & 0.07 & 0.01 \\
\hline India & 2658 & 0.03 & 366.80 & 0.02 & 42.1 & 0.03 & 1.35 & 0.18 \\
\hline Korea & $1,598.10$ & 0.02 & 616.90 & 0.03 & 12.1 & 0.01 & 0.05 & 0.01 \\
\hline Australia & $1,340.00$ & 0.02 & 325.00 & 0.02 & 68 & 0.05 & 0.02 & 0.00 \\
\hline Brunei & 12.7 & 0.00 & 6.90 & 0.00 & 0.4 & 0.00 & 0.0004 & 0.00 \\
\hline Cambodia & 22.2 & 0.00 & 15.90 & 0.00 & 3.2 & 0.00 & 0.016 & 0.00 \\
\hline Indonesia & 999.1 & 0.01 & 195.70 & 0.01 & 15.5 & 0.01 & 0.267 & 0.04 \\
\hline Laos & 17.4 & 0.00 & 6.70 & 0.00 & 1.3 & 0.00 & 0.007 & 0.00 \\
\hline Malaysia & 348.6 & 0.00 & 255.00 & 0.01 & 7.6 & 0.01 & 0.031 & 0.00 \\
\hline Myanmar & 75 & 0.00 & 20.20 & 0.00 & 3.5 & 0.00 & 0.002 & 0.00 \\
\hline Philippines & 354.6 & 0.00 & 75.90 & 0.00 & 6.6 & 0.00 & 0.106 & 0.01 \\
\hline Singapore & 337.9 & 0.00 & 492.60 & 0.02 & 79.7 & 0.05 & 0.005 & 0.00 \\
\hline Thailand & 449.2 & 0.01 & 263.20 & 0.01 & 10.3 & 0.01 & 0.069 & 0.01 \\
\hline Vietnam & 234.7 & 0.00 & 259.20 & 0.01 & 15.5 & 0.01 & 0.095 & 0.01 \\
\hline New Zealand & 196.9 & 0.00 & 41.50 & 0.00 & 1.9 & 0.00 & 0.006 & 0.00 \\
\hline ASEAN & $2,851.90$ & 0.03 & $1,596.80$ & 0.08 & 148.9 & 0.10 & 0.65 & 0.09 \\
\hline RCEP (less India) & $23,899.90$ & 0.29 & $5,953.30$ & 0.28 & 379.10 & 0.25 & 2.29 & 0.30 \\
\hline ASEAN+3 & $22,363.00$ & 0.27 & $5,586.80$ & 0.27 & 309.2 & 0.21 & 2.26 & 0.30 \\
\hline ASEAN-China & $16,228.00$ & 0.20 & $4,221.70$ & 0.20 & 287.20 & 0.19 & 2.08 & 0.27 \\
\hline ASEAN-Korea & $4,450.00$ & 0.05 & $2,213.70$ & 0.11 & 161.00 & 0.11 & 0.70 & 0.09 \\
\hline ASEAN-Japan & $7,388.80$ & 0.09 & $2,344.70$ & 0.11 & 158.70 & 0.11 & 0.78 & 0.10 \\
\hline ASEAN-ANZ & $4,388.80$ & 0.05 & $1,963.30$ & 0.09 & 218.80 & 0.15 & 0.68 & 0.09 \\
\hline EU & $14,511.10$ & 0.18 & $6,343.20$ & 0.30 & 349.8 & 0.23 & 0.51 & 0.07 \\
\hline NAFTA & $22,516.70$ & 0.27 & $2,897.10$ & 0.14 & 331.7 & 0.22 & 0.49 & 0.06 \\
\hline СРТРР & $10,384.40$ & 0.13 & $3,246.10$ & 0.15 & 274.8 & 0.18 & 0.5 & 0.07 \\
\hline
\end{tabular}

(Source) Computed from UNCTAD, Handbook of Statistics (2017). 
Table A2. Average Applied Tariffs on Imports from ASEAN to Australia, 2007-2016

\begin{tabular}{lcccccccccc}
\hline & 2007 & 2008 & 2009 & 2010 & 2011 & 2012 & 2013 & 2014 & 2015 & 2016 \\
\hline Brunei & 0.00 & 0.00 & 0.00 & 0.00 & 0.00 & 0.00 & 0.00 & 0.00 & 0.00 & 0.00 \\
Cambodia & 0.01 & 0.02 & 0.01 & 0.01 & 0.01 & 0.02 & 0.01 & 0.01 & 0.01 & 0.01 \\
Indonesia & 0.01 & 0.01 & 0.01 & 0.01 & 0.01 & 0.01 & 0.01 & 0.01 & 0.02 & 0.05 \\
Laos & 0.01 & 0.10 & 0.05 & 0.04 & 0.02 & 0.00 & 0.00 & 0.04 & 0.02 & 0.01 \\
Malaysia & 0.01 & 0.01 & 0.01 & 0.01 & 0.00 & 0.02 & 0.02 & 0.01 & 0.01 & 0.02 \\
Myanmar & 0.00 & 0.00 & 0.00 & 0.00 & 0.00 & 0.00 & 0.00 & 0.00 & 0.00 & 0.00 \\
Philippines & 0.02 & 0.02 & 0.03 & 0.02 & 0.07 & 0.07 & 0.02 & 0.01 & 0.01 & 0.00 \\
Singapore & 0.01 & 0.01 & 0.01 & 0.01 & 0.03 & 0.04 & 0.06 & 0.08 & 0.20 & 0.41 \\
Thailand & 0.01 & 0.01 & 0.00 & 0.00 & 0.00 & 0.00 & 0.00 & 0.00 & 0.00 & 0.00 \\
Vietnam & 0.01 & 0.01 & 0.01 & 0.00 & 0.00 & 0.00 & 0.00 & 0.00 & 0.01 & 0.01 \\
\hline
\end{tabular}

Table A3. Empirical Results for Preferential Margins of FTAs and Utilization in the AANZFTA Area with Lags

\begin{tabular}{|c|c|c|c|c|}
\hline Variables & (1) & (2) & (3) & (4) \\
\hline \multirow[t]{2}{*}{ Margin } & $1.316^{* * *}$ & $1.315^{* * *}$ & $1.319^{* * *}$ & $1.310 * * *$ \\
\hline & $(0.037)$ & $(0.037)$ & $(0.036)$ & $(0.036)$ \\
\hline \multirow[t]{2}{*}{ Ln (Imports) } & $0.007 * * *$ & $0.007 * * *$ & $0.010^{* * *}$ & $0.010 * * *$ \\
\hline & $(0.0003)$ & $(0.0003)$ & $(0.0008)$ & $(0.0008)$ \\
\hline \multirow[t]{2}{*}{ Lagged Utilization } & $0.625 * * *$ & $0.624 * * *$ & $0.629 * * *$ & $0.629 * * *$ \\
\hline & $(0.008)$ & $(0.008)$ & $(0.008)$ & $(0.008)$ \\
\hline Lagged Ln (Imports) & - & - & $\begin{array}{c}-0.004 * * * \\
(0.0008)\end{array}$ & $\begin{array}{c}-0.004 * * * \\
(0.0008)\end{array}$ \\
\hline \multirow[t]{2}{*}{ Constant } & $-0.093 * * *$ & $-0.093 * * *$ & $-0.083 * * *$ & $-0.083 * * *$ \\
\hline & $(0.0015)$ & $(0.0015)$ & $(0.015)$ & $(0.015)$ \\
\hline Observations & 35,521 & 35,521 & 35,521 & 35,521 \\
\hline Country-Product & 11,348 & 11,348 & 11,348 & 11,348 \\
\hline R-Squared & 0.69 & 0.69 & 0.70 & 0.70 \\
\hline Exporter Dummies & YES & YES & YES & YES \\
\hline Year Fixed Effects & NO & YES & NO & YES \\
\hline ROO Dummies & YES & YES & YES & YES \\
\hline Exporter-Year & YES & YES & YES & NO \\
\hline Exporter-Product & YES & YES & YES & YES \\
\hline
\end{tabular}

Robust standard errors are in parentheses; *** $p<0.01,{ }^{* *} p<0.05, * p<0.1$ 